\title{
Visual Diplomacy: Reflections on Diplomatic Spectacle and Cinematic Thinking
}

\author{
Costas M. Constantinou \\ Department of Social and Political Sciences, University of Cyprus, Nicosia \\ constantinou.m.costas@ucy.ac.cy
}

Received: 10 April 2017; revised: 14 October 2017; accepted: 15 January 2018

\section{Summary}

In engaging the visual aspects of public diplomacy, this article has three objectives. First, it introduces the notion of visual diplomacy - the ways and means by which images are used by plural diplomatic actors to transmit ideas to audiences, producing and circulating meanings that serve particular purposes, with the aim of influencing, shaping and transforming relations between actors and across publics. Second, it examines how the spectacle of diplomacy is enacted by focusing on a particular case of commissioned cinematography of Cypriot public diplomacy. Third, it engages visual diplomacy cinematically, employing Deleuze's insights on the cinematic apparatus, and by producing an essay film, The Blessed Envoy, linked to this article. The film reuses, through creative montage, nine official documentaries of Cypriot public diplomacy, revealing the key narratives and hidden transcripts that the visual material disseminates, thus encouraging a reflexive focus on the use of imagery in diplomacy.

* Research for this article and the essay film that accompanies it was made possible by a Leventis Foundation research grant for the project 'Cypriot Presence and Public Diplomacy in Sub-Saharan Africa: A Historical Perspective' (2014-2016). My thanks to Maria Tselepou and Marinos Papaiokaeim, who digitised the Makarios documentaries and converted references to The Hague Journal of Diplomacy's citation format. In preparing the essay film, I benefited from the very useful comments offered during pre-screenings by Dimitris Antoniou, Karen Emmerich, Mete Hatay, Sam Okoth Opondo, Andri Panayiotou, Christodoulos Panayiotou, Yiannis Papadakis, Nicos Philippou, Lia Spyridou, Nicos Trimikliniotis and Konstantina Zanou. Finally, for the article, I benefited from the discussion following presentations at the EISA Barcelona conference in September 2017 and the International Relations workshop at the University of Cyprus in February 2017, and the constructive comments of two anonymous reviewers and the editors of The Hague Journal of Diplomacy. 


\section{Keywords}

public diplomacy - visual culture - cinematic apparatus - essay film - postcoloniality - Cyprus

\section{Note on Reading the Article and Accessing the Essay Film}

An integral part of this article is the essay film The Blessed Envoy, written and directed by Costas M. Constantinou. The reader is strongly encouraged to view the essay film first, so as to appreciate visually the specific points and references in the article below. The Blessed Envoy is available online at https://vimeo.com/215142076 (using the password: Makarios).

\section{Understanding Visual Diplomacy}

There is not a more illustrious Theatre than a Court; neither is there any Comedy, where the actors seem less what they are in effect, than Embassadors do in their Negotiation.

ABRAHAM DE WICQUEFORT ${ }^{1}$

Film-drama is the opium of the people. Down with the immortal kings and queens of the screen! ... Down with the staging of everyday life!

DZIGA VERTOV ${ }^{2}$

The brain is the screen.

GILLES DELEUZE ${ }^{3}$

Diplomacy has traditionally been associated with verbal communication, dialogue and the artful use of language in advocating positions, negotiating

1 Abraham de Wicquefort, The Embassador and his Functions (1681/1716), reprinted by the Centre for the Study of Diplomacy, University of Leicester (1997), p. 294.

2 Dziga Vertov, Kino-Eye: The Writings of Dziga Vertov, edited by Annette Michelson (Berkeley, CA: University of California Press, 1984), p. 71.

3 Gilles Deleuze, 'The Brain is the Screen: An Interview with G. Deleuze', in Gregory Flaxman (ed.), The Brain is the Screen: Deleuze and the Philosophy of Cinema (Minneapolis, MN: University of Minnesota Press, 200o), p. 366. 
interests and drafting agreements. ${ }^{4}$ Although not given as much attention in diplomatic studies, the visual dimension has also been analysed whenever diplomacy is approached as a multifaceted exercise, and not simply as a logocentric practice. Suffice to consider the dramatic staging and televising of diplomatic summits and all that surrounds them, the extreme care paid to etiquette and ceremonial appearances, and the non-verbal signalling across the diplomatic profession through attire, posturing and facial expression. ${ }^{5}$

Why should we be concerned with visual diplomacy? Primarily because the artful use of visuals has come out of the 'illustrious theatre' of the court and become a highly significant aspect of public diplomacy. Visuality creates a heightened awareness of 'the event', working on the emotions of the multitude and cultivating iconic images with a lasting impact on them. It is increasingly prevalent in the twenty-first century, an epoch characterized by the 'mediatization of diplomacy' - that is, the intense production and circulation of images and words through global mass media. ${ }^{6}$ Recent technological advances in digital communications provide diplomatic actors with ample new opportunities to create, store, reproduce and disseminate audio-visual material. ${ }^{7}$ In terms of diplomatic practice, the visual aspect was officially regulated by protocol and controlled by state media. The pluralist, multi-stakeholder diplomacy of the current age, however, has greatly expanded the diplomatic space - extended the 'illustrious theatre' - creating asymmetrical representational capabilities and possibilities. ${ }^{8}$ This has led ultimately to 'a post-protocol world of diplomacy in which imagery is used by multiple actors, operating at multiple levels, and

4 Harold Nicolson, Diplomacy (Oxford: Oxford University Press, 1963); Adam Watson, Diplomacy: The Dialogue between States (London: Methuen, 1982); Donna Oglesby, 'Diplomatic Language', in Costas M. Constantinou, Pauline Kerr and Paul Sharp (eds), The SAGE Handbook of Diplomacy (London: Sage, 2016), pp. 242-254.

5 Raymond Cohen, Theatre of Power: The Art of Diplomatic Signalling (London: Longman, 1987); Christer Jönsson and Martin Hall, 'Communication: An Essential Aspect of Diplomacy', International Studies Perspectives, vol. 4, no. 2 (2003), pp. 195-210; Andrew Cooper, Celebrity Diplomacy (New York: Routledge, 2015).

6 James Pamment, 'The Mediatization of Diplomacy', The Hague Journal of Diplomacy, vol. 9, no. 3 (2014), pp. 253-280.

7 Corneliu Bjola and Marcus Holmes (eds), Digital Diplomacy: Theory and Practice (New York: Routledge, 2015).

8 Geoffrey Wiseman, 'Polylateralism' and New Modes of Global Dialogue, Discussion Paper no. 59 (Leicester: Leicester Diplomatic Studies Programme, 1999); and Andrew F. Cooper and 
pursuing multiple objectives. ${ }^{9}$ In other words, all kinds of diplomatic (or potentially diplomatic) actors - state and non-state — currently employ visuals to gain public outreach and support their objectives.

Going beyond its appreciation and employment in diplomatic practice, the role of visuality has already been broached in the academic fields of International Relations (IR) and Global Politics. The visual or pictorial turn as a critical method highlights how imagery documents and constructs 'reality', as well as the way in which imagery is complexly entangled with verbal accounts, identity formation, security concerns and the politics of representation more broadly. Several scholars have addressed these issues and developed different methodologies for analysing visual global politics. ${ }^{10}$ Furthermore, a number of scholars have specifically used films in explaining and understanding key concepts and issues in global politics. ${ }^{11}$ Finally, a few IR scholars have

Brian Hocking, 'Governments, Non-Governmental Organizations and the Recalibration of Diplomacy', Global Society, vol. 14, no. 3 (2000), pp. 361-376.

Costas M. Constantinou, 'Diplomacy', in Ronald Bleiker (ed.), Visual Global Politics (New York: Routledge, 2018), pp. 104-110.

Among others, see Michael Shapiro, The Politics of Representation: Writing Practices in Biography, Photography, and Policy Analysis (Madison, wi: University of Wisconsin Press, 1988); Costas M. Constantinou, 'Diplomatic Representations ... or Who Framed the Ambassadors?', Millennium, vol. 23, no. 1 (1994), pp.1-23; Gillian Rose, Visual Methodologies: An Introduction to Researching with Visual Materials (London:Sage, 2001); David Campbell, 'Cultural Governance and Pictorial Resistance: Reflections on the Imaging of War', Review of International Studies, vol. 29 (2003), pp. 57-73; Lene Hansen, 'Theorizing the Image for Security Studies: Visual Securitization and the Muhammad Cartoon Crisis', European Journal of International Relations, vol. 17, no. 1 (2011), pp. 51-74; Ronald Bleiker, 'Pluralist Methods for Visual Global Politics', Millennium - Journal of International Studies, vol. 43, no. 3 (2015), pp. 872-89o; and Axel Heck and Gabi Schlag, 'Securitizing Images: The Female Body and the War in Afghanistan', European Journal of International Relations, vol. 19, no. 4 (2013), pp. 891-913.

Among others, see Michael Shapiro, Cinematic Political Thought: Narrating Race, Nation, and Gender (New York: New York University Press, 1999); Jutta Weldes, 'Going Cultural: Star Trek, State Action, and Popular Culture', Millennium, vol. 28, no. 1 (1999), pp. 117-134; Iver Neumann, 'Grab a Phaser, Ambassador": Diplomacy in Star Trek', Millennium, vol. 30, no. 3 (2001), pp. 603-624; Cynthia Weber, 'The Highs and Lows of Teaching IR Theory: Using Popular Films for Theoretical Critique', International Studies Perspectives, vol. 2, no. 3 (2001), pp. 281-287; Klaus Dodds, 'Licensed to Stereotype: Geopolitics, James Bond and the Spectre of Balkanism', Geopolitics, vol. 8, no. 2 (2003), pp. 25-156; and William Callahan, 'The Visual Turn in IR: Documentary Filmmaking as a Critical Method', Millennium, vol. 43, no. 3 (2015), pp. 891-910. 
directed films themselves, illustrating and supporting their research findings, while reaching wider audiences. ${ }^{12}$

Following on Guy Debord's pioneering work, it can be argued that the spectacle has become the dominant form of representation in modern society, supplanting the actuality of social experience and serving as a paradigm of power. Power is not just exercised through the words of force and the force of words. It is also exercised through the effects and affects of the now globalized illustrious theatre. For Debord, the spectacle's 'specialized role is that of spokesman for all other activities, a sort of diplomatic representative of hierarchical society at its own court, and the source of the only discourse which that society allows itself to hear.'13 Reversely thought, but aptly in an era of public diplomacy, the spectacle has become a form of diplomacy through which the repertoire of images is orchestrated for mass consumption. Images often speak louder than words and activities, and in this regard all activities are spoken in advance or framed by images and imagers. For Debord, the spectacle entails not just the assembly and ordering of images, but the social construction of relationships mediated increasingly if not exclusively through imagery. As Debord puts it, 'the spectacle is not a collection of images; rather, it is a social relation among people mediated by images.' ${ }^{14}$ The spectacle is the relation; the image a kind of non-human diplomat mediating that relationship; the dramas of this other illustrious theatre dominate over social life.

If Debord's polemical thesis is correct that diplomacy and visuality are conceptually linked, focusing on 'visual diplomacy' is an obvious move for fully appreciating this entanglement. We may define visual diplomacy as the ways and means by which images - still or moving images, often in combination with verbal comment or aural background - are used by plural diplomatic actors to transmit ideas to audiences, producing and circulating meanings that serve particular purposes, with the aim of influencing, shaping and transforming relations between actors and across publics. Visual diplomacy is thus approached as a key aspect of public diplomacy, seeking to influence 'foreign' as well as 'domestic' publics, and serving the instrumental armoury of different actors, their policy pursuits and image-branding. We should keep in mind, however, that

\footnotetext{
12 See, for example, Cynthia Weber, 'I Am an American' film project; and, further, Cynthia Weber, 'I am an American': Filming the Fear of Difference (Bristol: Intellect Books, 2011); James Der Derian, David Udris and Michael Udris, 'Human Terrain' (2010); and Costas M. Constantinou and Giorgos Skordis, 'The Third Motherland' (2011).

13 Guy Debord, The Society of the Spectacle (New York: Zone Books, 1994), section 32, my emphasis.

14 Debord, The Society of the Spectacle, section 4.
} 
the visual also figures in the 'new public diplomacy' — that is, as an interactive process of communication and knowledge-building across transnational actors and audiences, which at the very least entails meaningful exchange on the merits of opposing views and positions..$^{15}$ Public diplomatic engagements and their dissemination of visuals could potentially — and should — encourage reflexivity and comparative awareness with regard to the construction of self/ other identities and hegemonic vis-à-vis transformative narratives. ${ }^{16}$

What is at stake in conducting diplomacy publicly and visually? In answering this question, it helps to utilize Max Weber's thoughts on political vocation. ${ }^{17}$ On the one hand, just like politics, diplomacy is exercised within an 'ethic of ultimate ends'. This means that its driving force is the successful implementation of policy, targeting specific ends that are presented as morally unobjectionable and justifying the means employed to achieve them. On the other hand, diplomatic practitioners also espouse an 'ethic of responsibility' concerning the consequences of their actions, considering the implications on others of achieving specific ends or employing specific means. ${ }^{18}$ In other words, the various instruments that diplomacy employs should be viewed not only from the perspective of 'us' but also from that of diverse 'others' and the adverse impact that diplomatic ways and means may have on them. The instrumental use of visuals should likewise be constantly reviewed with concern to the representation of 'others' vis-à-vis the plots and narratives that support 'us'.

15 See Jan Melissen (ed.), The New Public Diplomacy: Soft Power in International Relations (Basingstoke: Palgrave Macmillan, 2005); Brian Hocking, 'Rethinking the "New" Public Diplomacy', in Jan Melissen (ed.), The New Public Diplomacy, pp. 28-43; Kathy Fitzpatrick, 'Advancing the New Public Diplomacy: A Public Relations Perspective', The Hague Journal of Diplomacy, vol. 2, no. 3 (2007), pp. 187-211; Bruce Gregory, 'Public Diplomacy: Sunrise of an Academic Field', The Annals of the American Academy of Political and Social Science, vol. 616, no. 1 (2008), pp. 274-29o; and Nicholas Cull, 'Public Diplomacy: Seven Lessons for its Future from its Past', Place Branding and Public Diplomacy, vol. 6, no. 1 (2010), pp. 11-17.

16 See Anthony Deos and Geoffrey Allen Pigman, 'Sustainable Public Diplomacy: Communicating about Identity, Interests and Terrorism', in Costas Constantinou and James Der Derian (eds), Sustainable Diplomacies (Basingstoke: Palgrave Macmillan, 2010), pp. 151-172.

17 Max Weber, 'Politics as a Vocation', in H.H. Gerth and C. Wright Mills (eds), From Max Weber: Essays in Sociology (London: Routledge, 1991), pp. 77-128.

18 Weber, 'Politics as a Vocation', pp. 120-127. For more on diplomatic ethics, including the issue of limited agency, loyalty conflicts and ethical reflection-in-action, see Corneliu Bjola, 'Diplomatic Ethics', in Costas M. Constantinou, Pauline Kerr and Paul Sharp (eds), The SAGE Handbook of Diplomacy (London: Sage, 2016), pp. 123-132. 
What might an ethic of visual diplomacy entail? If 'the brain is the screen', as Gilles Deleuze encourages us to consider, how do we diplomatically and cinematically engage with the mental screen? Diplomacy operates on the basis of the two ethical dispositions outlined above; likewise for visual diplomacy, with particular reference to how these ethical dispositions valorise the making or unmaking of the 'viewpoint'. On the one hand, the diplomatic ethic of ultimate ends works in and through the fixing of 'the viewpoint' and 'the culmination of the illusion' for the viewer - the assemblage of images peaking in particular plots and narratives that enhance the static or dominant viewpoint. ${ }^{19}$ On the other hand, the diplomatic ethic of responsibility utilizes a different kind of cinematography - the mobility of the camera shots and the creativity of montage in reassembling images so as to bring about 'emancipation of the view point'. ${ }^{20}$ Visual diplomacy espouses one or the other ethic, or occasionally a mixture of both ethics, whenever instrumentalisation is combined with reflexivity over the projected viewpoint.

The next section explains how the cinematic apparatus can be utilized for the emancipatory possibility, opening up thinking space, producing not only 'common sense' but 'uncommon sense', following here on the work of Deleuze and Michael Shapiro on 'cinematic political thought'. ${ }^{21}$ The point is that we can think - not only instrumentally but also critically and creatively about the role of visuals and imagery - by thinking cinematically. Cinema can get us in and out of the spectacle, in and out of the dramas of the illustrious theatre, through the creative use of montage.

The 25-minute essay film The Blessed Envoy, written and directed by Costas M. Constantinou and linked to this article, is such an attempt to think cinematically about the diplomatic spectacle. It zooms in and out of the spectacle, and aims to sensitize the spectator to the official montage and dominant viewpoint that public diplomacy creates, the opiate and numbing effect that film drama produces. The latter is what Dziga Vertov criticizes in the epigraph, and explains his commitment to experimenting with essay filmmaking. ${ }^{22}$ In other words, rather than simply write about the diplomatic spectacle in an academic article, I decided to use montage as well, to experiment and to reassemble imagery creatively in a way that problematizes the dominant plots and narratives of the official spectacle, as explained in more detail below. To that extent, this essay film seeks to engage visual diplomacy actively and in its own

\footnotetext{
19 Gilles Deleuze, Cinema 1: The Movement-Image (London: Athlone Press, 1986), p. 3.

20 Deleuze, Cinema 1, p. 3.

21 Shapiro, Cinematic Political Thought.

22 For more, see Vertov, Kino-Eye.
} 
terms - that is, responding to the official visual diplomacy of the Republic of Cyprus with a counter-visual diplomacy that contextualizes, interprets and reassesses it. The Blessed Envoy can be accessed at https://vimeo.com/215142076 (using the password: Makarios), and — if not already watched — the reader should watch it now, as it will help in fully appreciating and following the argument below.

\section{The Essay Film and Cinematic Thinking}

The essay film format provides an innovative method of analysis and critique, as it follows a more experimental and reflexive approach to filmmaking. ${ }^{23}$ As explained by the main festival on the genre, "The essay film is a hybrid form that brings together elements of documentary and experimental filmmaking into a highly personal and often politically engaged mode of expression', which 'has flourished in the new era of digital filmmaking.. ${ }^{24}$ The emphasis of essay films is on critical filmmaking, as "The essay film is doubly an act of criticism. It engages critically with the forms of cinema and at the same time casts a critical eye on the world that cinema inhabits.' 5

Importing the idea of 'essay' into 'film' is meant to highlight the thinking and reflexivity that go into certain kinds of cinematic production. The essay suggests a particular form of writing and presenting ideas. According to Theodor Adorno, the essay does not aspire to the objectivity of scientific writing and systematic thinking; nor does it valorise method and its protocols in choosing analytical concepts and objects of research. The essay, by contrast, has an 'antisystematic impulse', 'introduces concepts unceremoniously' and follows an 'unmethodical method'. ${ }^{26}$ In a nutshell, it constitutes an open, experimental and reflexive mode of writing:

23 On this point, see Timothy Corrigan, The Essay Film: From Montaigne, after Marker (Oxford: Oxford University Press, 2011); David Montero, Thinking Images: The Essay Film as a Dialogic Form in European Cinema (Pieterlen: Peter Lang, 2012); and Erlend Lavik, 'The Video Essay: The Future of Academic Film and Television Criticism?', Frames Cinema Journal, no. 1 (2012), available online at http://framescinemajournal.com/article/ the-video-essay-the-future.

24 See http://www.essayfilmfestival.com/about.

25 See http://www.essayfilmfestival.com.

26 Theodor Adorno, 'The Essay as Form', in Theodor Adorno, Notes to Literature, volume 1 (New York: Columbia University Press, 1991), pp. 3-23, at pp. 12-13. 
The person who writes essayistically is the one who composes as he experiments, who turns his object around, questions it, feels it, tests it, reflects on it, who attacks it from different sides and assembles what he sees in his mind's eye and puts into words what the object allows one to see under the conditions created in the course of writing. ${ }^{27}$

The essay is therefore suggested to be the 'critical form par excellence', an 'immanent critique of intellectual constructions' and, to that extent, its 'innermost formal law is heresy'. ${ }^{28}$ The essay seeks to make visible what orthodox thinking renders invisible or peripheral.

To that extent, the genre of essay film includes a broad range of 'essayist' cinematography, which is sometimes used explicitly by the director and at other times ascribed post facto by the film historian and critic. The genre ranges from Dziga Vertov's Man with a Movie Camera (1929) to Luis Buñuel's surrealist and iconoclastic movies, to Jean-Luc Godard's engagement with film history, to Chris Marker's multimedia and cross-cultural ethnographies and to Adam Curtis's documentary meditations on self, power and politics. Consequently, the essay film has been viewed as a 'productively inventive' genre, which by 'straddling fiction and nonfiction, news reports and confessional autobiography, documentaries and experimental film', encourages 'practices that undo and redo film form, visual perspectives, public geographies, temporal organizations, and notions of truth and judgement within the complexity of experience. ${ }^{29}$

The essay film offers opportunities to illustrate and visually support critical engagement, exploring common themes and linkages across existing films or specially filmed footage. What seems common in all essay films is an alternative vision, musing on filmic enactment, and offering a sustained exposition of the dialogic tension between the verbal and the moving image. ${ }^{30}$ As one of the pioneers, Dziga Vertov, put it, the kino-eye or 'moving eye' approach sees 'that which the eye [normally] doesn't see', offers 'the possibility of making the invisible visible, $[\ldots]$ the hidden manifest, the disguised overt, the acted nonacted'. ${ }^{31}$ With respect to Gilles Deleuze, this tension is linked to the valorisation of cinematic spatio-temporality and its emancipatory potential vis-à-vis the 'actual' and the 'repetitive'.

\footnotetext{
27 Max Bense quoted in Adorno, 'The Essay as Form', p. 17.

28 Adorno, 'The Essay as Form', pp. 18 and 23.

29 Corrigan, The Essay Film, p. 4.

30 Corrigan, The Essay Film, p. 20.

31 Vertov, Kino-Eye, p. 41.
} 
For Deleuze, cinematic practice entails much more than producing films. Cinema is about the production of images projected on different screens and ultimately on the mind. The image is a slicing up of the world, and cinema a continuous framing and interlacing of images. ${ }^{32}$ To that extent, cinema should be understood as being inextricably connected not only to the visual artefacts that it shoots and projects, but also to those countless other images that it cuts and leaves out. Images function like crystals reflecting and refracting one another, and Deleuze gives a long typology of images, of which the movement-image and the time-image are the most important. Recognizing how images interlink and create plots helps us to understand cinematic thinking specifically, how this thinking enacts and delimits the world we see, while potentially also having the power to emancipate and enhance our vision.

Thinking is cinematic, because it is a movement in the world. ${ }^{33}$ We frame and cut, we move from one image to another, consciously or unconsciously. When we move consciously, it is as if we are directing; we are in charge of the montage and the collection of imagery. When we move unconsciously we are not in control of the montage; we are being directed and taken on a ride from one image to another. ${ }^{34}$ Yet as humans engage the world both consciously and unconsciously, one can say that we are both directing and being directed in our thinking. Becoming more conscious of this image movement (for example, how one image entices and is related to another, how image assemblage and montage bring about particular plots vis-à-vis other plots, and how convergence of action can threaten but also restore the unity of an organic set $)^{35}$ is the promise of cinema and the beginning of more critical thinking. As Deleuze puts it, 'the cinema is not only the camera: it is montage. And if from the point of view of the human eye, montage is undoubtedly a construction, from the point of view of another eye, it ceases to be one; it is the purest vision of a non-human eye, of an eye which would be in things. ${ }^{36}$ Differently put, cinema always entails the possibility of vision beyond the director's cinematic plot and narrative construction.

Important for critical thinking is the 'time-image'. This is because 'the modern cinema has discovered that the "time image" constitutes a way of reading events that is more critical than mere perception', and so it employs it

\footnotetext{
32 Deleuze, Cinema 1, pp. 12-28.

33 Deleuze, Cinema 1.

34 Cf. Christian Metz, Psychoanalysis and Cinema: The Imaginary Signifier (London: Macmillan, 1982).

35 Deleuze, Cinema 1, pp. 30-31.

36 Deleuze, Cinema 1, p. 81 .
} 
'to think about the time and value of the present'. ${ }^{37}$ As Michael Shapiro explains, Deleuze establishes a homology between cinematic practice and critical thinking of the present — that is, 'thinking in cinema and through cinema' and thinking the present image through historical and futuristic imagery.38 Humans employ time-images all the time, such as images infused with past and future, and employing memories and fantasies to recognize, figure out and navigate their present condition. This temporal dimension underscores that images of the present can always be rethought through a different visual narration, thus responding 'to the critical thinking of the orchestrated cinematic apparatus rather than the modes of consciousness of the film's characters'. ${ }^{39}$

Films are a mere by-product of cinematic thinking. But they can help us to think differently. Specifically, they can help us to come to terms with the temporal movement of the world, the improvisation of image arrangement and the collective becoming through montage. As Deleuze explains, 'cinema is not a universal or primitive language system', but a 'language correlate' that 'consists of movements and thought processes' and 'of points of view on these movements and processes'. ${ }^{40}$ On the one hand, cinema can create a 'psychological automaton' whereby the thinking human 'is disposed of his own thought and obeys the internal impression which develops solely in visions or rudimentary actions (from the dreamer to the somnambulist, and conversely through the intermediary of hypnosis, suggestion, hallucination, obsession, etc.). ${ }^{41}$ To use Guy Debord's terminology, the cinematic spectacle chains and disempowers the viewer, putting modern society to sleep. ${ }^{42}$ Or to follow Vertov's suggestion in the epigraph, it becomes the new religion and the opium of the people. On the other hand, when critically employed, cinema is 'a giant in the back of our heads', a 'spiritual automaton' that 'indicates the highest exercise of thought' and that can lead to free thinking and 'the fantastic effort of an autonomy'.43

From this perspective, cinema can be a powerful tool for self-consciousness and for social and political critique, enhancing the ethic of responsibility and balancing the ethic of ultimate ends. The cinematic apparatus offers a new way of approaching the collage of images that make up our world, at the same time as it shows the mind's creative (or not-so-creative) montage in

\footnotetext{
37 Shapiro, Cinematic Political Thought, p. 23.

38 Shapiro, Cinematic Political Thought, pp. 23-24.

39 Shapiro, Cinematic Political Thought, p. 25.

$40 \quad$ Gilles Deleuze, Cinema 2: The Time-Image (London: Athlone Press, 1989), p. 262.

41 Deleuze, Cinema 2, p. 263.

42 Debord, The Society of the Spectacle, section 21.

43 Deleuze, Cinema 2, p. 263.
} 
re-enacting these worlds. In short, the cinematic approach to thinking cultivated by Deleuze offers a sensitizing and reflexive approach to the partial worlds that the filmic experience creates.

\section{The Blessed Envoy}

The Blessed Envoy is a compilation of, and reflection on, nine documentaries that were filmed between 1962 and 1973. They are all short documentaries, chronicles or newsreels, covering official visits by the head of state or his special missions abroad, such as missionary work and group baptism. These documentaries were produced and screened primarily for Cypriot audiences, although some were also shown abroad, for example in India and Kenya. They chronicle the visits of Archbishop Makarios III - the first President of the Republic of Cyprus (1960-1977) - in the majority of cases to developing countries with which newly independent Cyprus had a special relationship through the Non-Aligned Movement. As explained to me in an interview in October 2013 with the key cinematographer of these documentaries, Polys Georgakis, the documentaries were personally commissioned by Makarios, and he was regularly consulted about what was to be covered in them. Furthermore, as acknowledged in the documentaries, the narration was not left to chance, but was written by Makarios's closest confidant and Deputy Minister of the Presidency, Patroclos Stavrou. Typically, they tend to eulogize both nation and leader. It is worth recalling, in this regard, that Makarios had a special interest in the filmic representation of himself and his policies, and even acted in a fiction film that depicted him as the object of an assassination plot. ${ }^{44} \mathrm{He}$ was an exemplary diplomatic virtuoso who liked to exhibit his 'bold' political moves and 'heroic' life. ${ }^{45}$

From this perspective, these early documentaries provide an official visual record of Cypriot public diplomacy, as it was intended to be viewed primarily back home and on some occasions abroad. In Cyprus, the documentaries were shown by the Cyprus Broadcasting Corporation $(\mathrm{CyBC})$, and were variously received by audiences that were inter- and intra-ethnically conflicted

44 Costas Constandinides and Yiannis Papadakis (eds), Cypriot Cinemas: Memory, Conflict, and Identity in the Margins of Europe (New York: Bloomsbury, 2014), pp. 1-2.

45 On the importance of focusing on the innovation and virtuosity of diplomatic agents, see Jeremy Cornut, 'Diplomacy, Agency and the Logic of Improvization and Virtuosity in Practice', European Journal of International Relations (2017, online first), DoI 10.1177/ 1354066117725156 . 
with regard to Makarios's policies. As we know, public diplomacy can produce diverse emotional responses from audiences of different national, class and ideological backgrounds. ${ }^{46}$ Even today, showing extracts from these old documentaries to different groups in Cyprus, mostly in academic circles, I received diverse and opposing responses from the audience. When two of these documentaries relating to Makarios's visits to Kenya were shown to groups in Nairobi and Mombasa in June and July 2015, the audience's response varied from bewilderment, taking offence at the representation of Africans in them, recognizing familiarity with the practices of colonial as well as African leaders, but also identifying positive differences and nuances vis-à-vis white colonial diplomacy and religious practice.

The documentaries that have been used in The Blessed Envoy were originally meant to present the grand national narrative of Cypriot diplomacy, and to that extent the essay film is an invitation to reflect on the ideas, values and plots that these visuals disseminated. On the one hand, The Blessed Envoy illustrates the seamless merging of 'imagetext', the range of visual narratives and hidden transcripts that official diplomacy produces, and thus the instrumental use of imagery and its world-enacting potential. On the other hand, it provides an outlook with regard to diplomacy's multifaceted exercise, encouraging consideration into its rationales and public manifestations, as well as the alternative narratives that are made possible through a different montage of camera shots. Needless to say, it is not an attempt to examine all the ramifications or explain all the workings of visual diplomacy. It is primarily a pedagogical tool enhancing visual media literacy among students and practitioners of diplomacy. It is also a vantage point from which to begin to think critically and creatively about the visual aspects of public diplomacy.

The choice of these documentaries to open up thinking space with regard to visual diplomacy is thus heuristic. The documentaries were not chosen on the basis of comparative optimal criteria, but were collected and digitized as part of a research project on 'Cypriot Presence and Public Diplomacy in Sub-Saharan Africa'. Given the official care and thinking that went into presenting the self to 'domestic' and 'foreign' publics, ${ }^{47}$ they adequately serve the purpose of showing the construction of meaning through official framing and montage. They

46 Sarah Ellen Graham, 'Emotion and Public Diplomacy: Dispositions in International Communications, Dialogue and Persuasion', International Studies Review, vol. 16, no. 4 (2014), pp. 522-539.

47 See Alisher Faizullaev, 'Diplomacy and Self', Diplomacy \& Statecraft, vol. 17, no. 3 (2006), pp. 497-522; and Rebecca Adler-Nissen, 'Diplomacy as Impression Management: Strategic Face-Work and Post-Colonial Embarrassment', cipss Working Paper no. 38 (2012). 
also reveal the highly contested diplomatic narratives that these documentaries disseminated to the targeted audiences, given the intra- and inter-ethnic clashes and divisions that characterized Cypriot political life at the time. The domestic public was deeply divided, and the ecclesiastical and Hellenocentric semiotic repertoire of these documentaries was ambivalently perceived at the time. This was also recalled by both the Greek Cypriots and Turkish Cypriots in the audience that watched the premiere of The Blessed Envoy at the Home for Cooperation in the UN Buffer Zone in Nicosia on 12 July 2017.

The Blessed Envoy provides a historical and perhaps peripheral example of visual diplomacy, but it resonates with the present time and current concerns. As with Deleuzian cinematic thinking, its time-images help us to 'think about the time and value of the present'. By watching these historical documentaries, we become acquainted with the cut, framing and assemblage of official montage. Moreover, we become familiarized with how the auditory component can support and bolster the visual. As shown by John Berger's masterful book and documentary on Ways of Seeing, by being able to reproduce images mechanically, and attach them to commentary and musical ambience, their meaning becomes easily transmittable but also diversified. ${ }^{48}$ Different music and commentary create different 'ways of seeing' in and through images.

The 'cinematic thinking' in the case of The Blessed Envoy takes the form of creative editing and explanatory analysis, while retaining the film's original footage, narration and music. The Blessed Envoy thus constitutes an experimental film, but also a meta-documentary — that is, a documentary of documentaries. Specifically, it aims to highlight the visual narratives of public diplomacy, the ideological parameters within which it operated, as well as the constitution of diplomatic subjectivity and performativity of particular identities. ${ }^{49}$ The Blessed Envoy seeks to expose the cultural particularities, intricacies and contested scripts of diplomacy ${ }^{50}$ that were operating within the newly established and ethnically divided state of Cyprus. As developed in more detail in the film, these early documentaries reveal how the public diplomacy of post-colonial Cyprus was a mixture of three scripts, a fusion of three visual narratives: the first was mimetic; the second anti-mimetic; and the

48 John Berger, Ways of Seeing (London: Penguin, 1972).

49 Cohen, Theatre of Power; Costas M. Constantinou, On the Way to Diplomacy (Minneapolis, MN: University of Minnesota Press, 1996); Iver Neumann, Diplomatic Sites: A Critical Enquiry (New York: Columbia University Press, 2012); and Jacob Ole Sending, Vincent Pouliot and Iver Neumann (eds), Diplomacy and the Making of World Politics (Cambridge: Cambridge University Press, 2015).

5o Pamment, 'The Mediatization of Diplomacy'; Melissen, The New Public Diplomacy. 
third transgressive. The article will now examine in turn each of these visual narratives.

\section{The Mimetic Script: Protocols and Tours}

The mimetic script closely imitated the paraphernalia of Western diplomatic ceremonies in high-profile venues. Mimesis as the copying and repetition of established practice is highly constitutive of meaning and identity in international relations. ${ }^{51}$ From this perspective, diplomacy's mimetic ceremonies defined the parameters of conventional meaning, recognition and semiotic exchange, at the same time as they provided publicity and status to the new leaders of the post-colony. The visual diplomacy of the Bandung Conference in 1955, which launched the global anti-colonial movement, is one such example. It has been described as following the 'performance of pageantry', which is 'entirely symbolic in nature' and meaningful 'through the participation of the audience, to the entire event'.52 Addresses at the United Nations or visits in imperial Ethiopia are another example, as presented in The Blessed Envoy.

The glamorous spectacles - from which colonial subjects were originally excluded but then joined in at independence - projected power, authority and legitimacy, albeit in sometimes ambiguous and vulgar forms. ${ }^{53}$ The leaders were supposed to embody sovereign statehood and their public diplomacies became emblematic of this new status. As symbolic events, they were intended to enhance the leaders' political capital at home and abroad. As shown in The Blessed Envoy, post-colonial leaders collaborated to magnify each other's celebrity cult, dramatizing their heroic deeds in all kinds of venues, via different narratives, as well as through high and popular culture.

The mimetic script primarily focused on the pomp and gear of diplomatic protocol. It underscored the grandeur that modern diplomacy had inherited

$5^{1} \quad$ Roland Bleiker, Aesthetics and World Politics (Basingstoke: Palgrave Macmillan, 2009); Necati Polat, International Relations, Meaning and Mimesis (New York: Routledge, 2012). On mimetic diplomatic practice, see Fiona McConnell, Terri Moreau and Jason Dittmer, 'Mimicking State Diplomacy: The Legitimizing Strategies of Unofficial Diplomacies', Geoforum, vol. 43, no. 4 (2012), pp. 804-814.

52 Naoko Shimazu, 'Performing "Freedom": The Bandung Conference as Symbolic Postcolonial Diplomacy', in Jason Dittmer and Fiona McConnell (eds), Diplomatic Cultures and International Politics: Translations, Spaces and Alternatives (New York: Routledge, 2016), pp. 59-76.

53 Achille Mbembe, 'The Banality of Power and the Aesthetics of Vulgarity in the Postcolony', Public Culture, vol. 4, no. 2 (1992), pp. 1-30. 
from the palaces and courts of Renaissance Europe. ${ }^{54}$ Transported into the post-colonial context, pageantry confirmed the new state's entrance into the international society of so-called 'normal' and 'civilized' states, whose leader deserved and was publicly granted all the markers and insignia of sovereignty. To this purpose, official arrival abroad was mimetically — and sometimes exaggeratedly — solemn and majestic.

The Blessed Envoy underscores the empire of signs that accompany a diplomatic event. These were translated through the official narration of the documentary into honours paid to Cyprus and its people. Although the choreographed reception of the leader by the multitude was a staged event, it was presented as a spontaneous display of love and affection for the Cypriot leader. Also, where circumstances allowed, historic links entered the script via tours of remembrance, which exalted the leader and exceeded traditional protocol. For example, Makarios's official visit to Kenya became an opportunity to recall his enforced exile to the Seychelles during the colonial period (1956-1957), passing on his way to exile through the port of Mombasa. Masses of Kenyan people were mobilized to greet and glorify Makarios's post-colonial return to Mombasa in 1970, and a street was named after him, leading to the point of his departure to exile.

Beyond protocol, however, these films mimicked white European ethnographic tours, in the way in which Cypriot visual diplomacy encountered and exoticized non-European people and their habitats. For Cypriots in the 196os, these documentaries provided a unique perspective into the 'outside world' and 'far-away places'. Thus, besides official events, the documentaries treated Cypriot audiences to a sightseeing tour of famous sites. It was also an ethnographic tour of unknown and exotic civilizations in Africa, Asia and Latin America. In this regard, the Cypriot head of state assumed the role of a European proto-anthropologist.

One of a number of examples shown in the essay film concerns Makarios's fascinating tour to Lake Nakoue in Benin in 1966. Taking viewers on an imaginative tour to a pre-modern state of being is a typical imitation of colonial modes of representation. ${ }^{55}$ Witnessing the lack of development in sub-Saharan Africa

54 Roy Strong, Splendor at Court: Renaissance Spectacle and the Theater of Power (Boston, MA: Houghton Mifflin, 1973); and Tony Spawforth, Versailles: A Biography of a Palace (New York: St Martin's Press, 2008).

55 Stanley Diamond, In Search of the Primitive: A Critique of Civilization (New York: Transaction Publishers, 1974); Edward Said, Culture and Imperialism (New York: Vintage, 1994); and Roxanne Lynn Doty, Imperial Encounters: The Politics of Representation in North-South Relations (Minneapolis, MN: University of Minnesota Press, 1996). More 
symbolically elevated the 'modern', 'Western' and 'developed' Cypriot state that Makarios represented and governed. The ethnographic gaze confirmed the hierarchy of the spectator vis-à-vis the native subjects who still 'lived back' in the 'early stages of human history', as expounded in the original narration.

With regard to the colonial element of such cinematic encounters with African 'exoticism' and 'backwardness', one can counterpoise other documentary films that emerged a few decades before the documentaries on Makarios. For instance, colonial projects such as the Bantu Educational Kinema Experiment (BEKE, 1935-1937), which began with the recognition that 'Bantu youth, and particularly Christian youth, who had undergone training in mission or government schools, tend to live in a world that is quite alien and unintelligible to the elders of their villages. ${ }^{\prime 6}$ Such cinematic projects set out to 'bridge the gap' between the different parts of the native population, using cinema for instruction and education. ${ }^{57}$ These films sought to make visible and explain 'to older men and women the new world and the new ideas' that they were increasingly encountering, for example in films like Tropical Hookworm (1936), Veterinary Training of African Natives (1936) and African Peasant Farms: The Kingolwira Experiment (1936). ${ }^{58}$ Unlike documentaries on Makarios, these instructional films were meant primarily for an 'African audience', employing African actors in evolutionary time, and explaining the new state of affairs in highly moralistic and pedantic modes. To that extent, the cinematic apparatus became an extension of colonial rationality by making the case for 'modern' habits and values required for the colonial governance to work and succeed. ${ }^{59}$

Beyond 'primitive' life, Makarios's encounters with the African jungle and animal kingdom had been equally dramatic and symbolically empowered the visiting head of state. Makarios pointedly visited many national parks in Africa and in one instance he led a Safari tour in Tanzania in 1970, where he was filmed displaying 'fortitude' and 'heroism'. While the audience is informed that

specifically, on the relationship between 'diplomatic practice' and 'critical geographical knowledge', see Merje Kuus, “To Understand the Place”: Geographical Knowledge and Diplomatic Practice', The Professional Geographer, vol. 68, no. 4 (2016), pp. 546-553.

56 L.A. Notcutt and G.C. Latham, The African and the Cinema: An Account of the Work of the Bantu Educational Cinema Experiment during the Period March 1935 to May 1937 (London: Edinburgh House Press, 1937), p. 9 .

On BEKE and other cinematic colonial projects, see Sam Okoth Opondo, 'Cinema is Our "Night School": Appropriation, Falsification, and Dissensus in the Art of Ousmane Sembène', African Identities, vol. 13, no. 1 (2015), pp. 34-48.

$5^{8}$ See online at http://www.colonialfilm.org.uk/production-company/bekefilm for these and other colonial films.

59 See, further, Opondo, 'Cinema is Our "Night School". 
'no visitor can leave the car for security reasons', Makarios 'exhibits boldness and courage because he has been through similar instances with humans'. The zoological encounter was thus visually interlinked with the leader's superiority, as well as with his political and diplomatic struggles. In this regard, it very much imitated the safari culture of white European tours, which pictorially celebrated supremacy and machismo. ${ }^{60}$

\section{The Anti-Mimetic Script: Orthodox Envoy}

These early documentaries also portray an anti-mimetic visual narrative, which highlighted how the Cypriot leader distinctly differed from other heads of state, notably by being not only a political but a religious leader, an envoy of Cyprus but also of God. The Biblical term Makarios means 'the Blessed One'. The Cypriot leader thus embodied the Orthodox envoy 'coming in the name of the Lord', ${ }^{61}$ promising redemption and salvation. As shown with other cases of post-colonial diplomacy elsewhere - for example with regard to the spiritual influences of Indian diplomacy ${ }^{62}$ - it would be wrong simply to read Eurocentric concepts and influences in diplomatic practice. Such Eurocentric legibility misses ideological diversions and particularities that support symbolic and distinctive characteristics in diplomatic practice.

Cypriot post-colonial diplomacy had such a distinctive national feature. Its leader was not like any other head of state, with the exception of the Holy See and later the Islamic Republic of Iran. He was the archbishop of an autocephalous church, who was addressed as His Beatitude. Given the heteronomy of the international system and diplomatic order, 'fringe players' and 'liminal political subjectivities' have the ability to project power and influence and can be immensely creative in practising diplomacy. ${ }^{63}$ In religious hierarchy, the archbishopric status gave Makarios added symbolic capital. He was accorded

6o Edward Steinhart, 'Hunters, Poachers and Gamekeepers: Towards a Social History of Hunting in Colonial Kenya', The Journal of African History, vol. 30, no. 2 (1989), pp. 247-264; Andrew Norton, 'Experiencing Nature: The Reproduction of Environmental Discourse through Safari Tourism in East Africa', Geoforum, vol. 27, no. 3 (1996), pp. 355-373; and John MacKenzie, The Empire of Nature: Hunting, Conservation and British Imperialism (Manchester: Manchester University Press, 1997).

$61 \quad$ Psalms 117:26.

62 Deep Datta-Ray, The Making of Indian Diplomacy: A Critique of Eurocentrism (Oxford: Oxford University Press, 2015).

63 See Jozef Bátora, Fringe Players and the Diplomatic Order: The 'New' Heteronomy (Basingstoke: Palgrave Macmillan, 2014); and Fiona McConnell, 'Liminal Geopolitics: The 
predominance in religious ceremonies and had access to ecclesiastical events. From the perspective of secular diplomacy, such a spectacle was rather strange, yet his office disseminated a spiritual and primordial sovereignty that had existed before colonial rule and continued after decolonization. ${ }^{64}$ This allowed him to practise forms of religious diplomacy and to brand Cyprus internationally through the niche of the Orthodox tradition and its historical legacy in the island, including its linkage to the anti-colonial struggle. ${ }^{65}$ But he also skilfully branded himself through Cyprus - shifting 'island' to 'I land' as one Cypriot artist coined it in an exhibition of Makarios's historical photos. ${ }^{6} 6$

His religious diplomacy extended beyond the Global South. For example, Makarios's controversial visit to the Soviet Union in 1971 was framed as a visit for the enthronement of the Russian Patriarch. By officiating in the enthronement of an important Russian institution, where representatives from all of the churches participated and by being given prominence over the others because he was also a head of state, little Cyprus became big in Moscow.

Besides the Orthodox denomination, Makarios was presented as a progressive religious leader, comfortable with other Christian leaders, and open to inter-church dialogue and reconciliation. He figured as an attentive Orthodox patriarch who was respectful of other sects and versions of Christianity, conversing with Catholic, Lutheran, Assyrian, Coptic, Ethiopian Orthodox and other branches of the faith. He was also repeatedly shown to enjoy the respect of leaders of other religions, be they Hindus and Jains in India, Zen Buddhists in Japan, or Muslims in Zanzibar. In short, in these documentaries his visits visually narrate a meeting and a dialogue of civilizations. Through this diplomatic spectacle, he is elevated to a master diplomat mediating international and inter-civilizational estrangement. ${ }^{67}$

Finally, there were instances where the religious mission completely dominated over the secular diplomatic mission. A notable example was the

Subjectivity and Spatiality of Diplomacy at the Margins', Transactions of the Institute of British Geographers, vol. 42, no. 1 (2017), pp. 139-152.

64 Partha Chatterjee, The Nation and its Fragments: Colonial and Postcolonial Histories (Princeton, NJ: Princeton University Press, 1993).

65 Philip Seib (ed.), Religion and Public Diplomacy (New York: Springer, 2013); and Costas M. Constantinou and Maria Tselepou, 'Branding Orthodoxy: Religious Diplomacy and the Makarios Legacy in Sub-Saharan Africa', Place Branding and Public Diplomacy, vol. 13, no. 3 (2017), pp. 179-193.

66 Christodoulos Panayiotou, 'I Land' Exhibition in Cubitt (London, 2010), see online at http://www.kamelmennour.com/media/8024/christodoulos-panayiotou-i-land.html.

67 James Der Derian, On Diplomacy: A Genealogy of Western Estrangement (Oxford: Blackwell, 1987). 
missionary work that Makarios conducted in Africa, something that both rebranded Orthodoxy in the region and legitimated his position as a religious leader back in Cyprus. ${ }^{68}$ For example, in the documentary Mission to Kenya (1971), Africans are shown as travelling from faraway places and gathering en masse in order to be baptized by the Blessed Envoy. Through this token missionary work, the Cypriot head of state reaffirmed his religious credentials as someone who not only took his ecclesiastical vocation seriously, but who had the ability to missionize, convert and expand the Orthodox faith around the globe. His group baptism was presented in this specific documentary as a momentous event that, with regard to Orthodoxy, had not occurred for at least a millennium.

\section{The Transgressive Script: Hellenic Envoy}

Finally, there was a transgressive script that was especially alarming to the Turkish-Cypriot community. Following the inter-communal clashes of 1963 , the Cypriot polity changed from being an officially bi-communal state to becoming an effectively mono-communal one under the control of the majority Greek-Cypriot community. Makarios's diplomacy controversially rekindled the international struggle to unite Cyprus with the 'Greek motherland' (enosis). In these documentaries, in line with Greek nationalist aspirations and contrary to the pronounced independence of Cyprus, there was a deliberate, transgressive effort to present the Cyprus republic as an extension of the Greek motherland. ${ }^{69}$

One striking example concerns Makarios's visit to 'Heroic Crete'. Following a long tour to Latin America, Makarios visited the island of Crete in 1966, joining the national celebrations of the Greek revolution against Ottoman rule. As the Cypriot archbishop and president, he proclaimed that he 'will continue the struggle of union with the motherland [Greece], firmly, without yielding or withdrawing, until the end, until victory'. Such images and proclamations, combined with special liturgies and celebratory parades, must have been especially disconcerting for the Turkish Cypriots. They were living in enclaves at the time, under precarious conditions and in a state of abandonment and

68 Constantinou and Tselepou, 'Branding Orthodoxy'.

69 Yiannis Papadakis, 'Greek Cypriot Narratives of History and Collective Identity: Nationalism as a Contested Process', American Ethnologist, vol. 25, no. 2 (1998), pp. 149165; and Rebecca Bryant, Imagining the Modern: The Cultures of Nationalism in Cyprus (London: Iв Tauris, 2004). 
exception. ${ }^{70}$ Consequently, far from being eased, their fear of a planned union with Greece was reconfirmed through these images and proclamations.

Beyond speeches, the Hellenization of the Republic of Cyprus was enacted through welcoming ceremonies and diplomatic protocol. During these official visits, the Greek flag was prevalent over the Cypriot one. This was not unreasonable given the ethno-cultural affiliation of Greek Cypriots abroad, who were naturally integrated with the Greek diaspora welcoming Makarios. ${ }^{71}$ However, there was also an insidious plan to project Greek identity exclusively and to fully Hellenize the state through international diplomacy, such as via the substitution of the Cypriot state's anthem with the Greek national anthem. This was officially introduced abroad during Makarios's visit to Panama in 1966.

Finally, these diplomatic visits celebrated the acknowledged 'greatness' of the Greek civilization that the Blessed Envoy was meant to embody. Encounters with foreign people were thus put within a trans-historical frame, reflecting back to the universalist legacy of ancient Greece and the aesthetics of recognition and appreciation that this 'dream' and 'beautiful' nation deserves. ${ }^{72}$ Again, in just one example among many, Makarios's encounter with the Maasai people in 1970 was framed as a historic meeting with 'the descendants of Alexander the Great'. The original narration of the documentary assuredly informs that the Maasai 'descend from soldiers of the Macedonian commander that lost their way in Egypt and went further down'. Thus, beyond aspiring to unite Cyprus with Greece, Makarios's visual diplomacy works to retrieve the lost Hellenes and link them to their forgotten patrias. Makarios's work on the field, his 'unofficial' public encounters while abroad, merge the known and unknown Hellenic worlds, project the mystical Hellas spread around the universe.

70 Costas M. Constantinou, 'On the Cypriot States of Exception', International Political Sociology, vol. 2, no. 2 (2008), pp. 145-164; and Rebecca Bryant and Mete Hatay, 'Guns and Guitars: Simulating Sovereignty in a State of Siege', American Ethnologist, vol. 38, no. 4 (2011), pp. 631-649.

71 For more on 'diaspora diplomacy' and specifically on how diplomacy is practised both through and by diaspora, see Elaine L.E. Ho and Fiona McConnell, 'Conceptualizing “Diaspora Diplomacy": Territory and Populations Betwixt the Domestic and the Foreign', Progress in Human Geography (2017, online first), DOI: 10.1177/0309132517740217.

72 Costas M. Constantinou, 'The Beautiful Nation: Reflections on the Aesthetics of Hellenism', Alternatives: Global, Local, Political, vol. 31, no. 1 (2006), pp. 53-75; and Stathis Gourgouris, Dream Nation: Enlightenment, Colonization, and the Institution of Modern Greece (Stanford, CA: Stanford University Press, 1996). 


\section{Epilogue}

By engaging the visual diplomacy of post-colonial Cyprus, The Blessed Envoy resonates with the present time and underscores the performative aspects of contemporary diplomatic practice. Specifically, diplomacy — in all its various facets and public expositions, and indeed in and through its visual operations can be instrumentally used to enact the state and other distinct identities on the world stage. ${ }^{73}$ It can also be used to disseminate ethno-cultural ideologies and narrate the grand deeds of the nation. ${ }^{74}$ In this way, it can legitimate a range of domestic and foreign policies. As shown in the essay film, it can also work to legitimate the deeds of our 'ordinary' and 'extraordinary' envoys, especially in the case of political leaders and heads of state, who continue with their illustrious theatrics and who nowadays get more opportunity to publicize widely their mimetic, anti-mimetic and transgressive activities. Abraham de Wicquefort, quoted in the epigraph, flagged the tragi-comic side of those courtly theatrics in the seventeenth century and how to the careful eye of the diplomatic theorist they would become nothing more than bad acting.

The 'self-reflexive focus on images' 75 that essay films encourage can provide an antidote to the instrumental use of imagery. Through the creativity of montage, essay films aim to provide another eye, a 'moving eye' to see anew or to see what is less visible, what the 'human eye' commonly misses. They can assist audiences and publics to become more conscious of the mechanisms through which visual diplomacy functions, sensitizing the spectators to the construction of subjectivity, the contested scripts and world-disclosing capacity of diplomacy, and consequently the multiple worlds that we need to recognize and negotiate in everyday life. ${ }^{76}$ The essay film provides, in short, a counter-montage seeking to emancipate the viewer from the official viewpoint and narrative. Spectators, and ultimately practitioners of diplomacy, are thus encouraged not to accept unreflectively and mimic unproblematically the convention, the symbolic moves inherited from the European colonial and

73 Constantinou, On the Way to Diplomacy; and Paul Sharp, Diplomatic Theory of International Relations (Cambridge: Cambridge University Press, 2009).

74 Homi Bhabha (ed.), Nation and Narration (New York: Routledge, 1990).

75 Montero, Thinking Images.

76 Lily Ling, The Dao of World Politics: Towards a Post-Westphalian, Worldist International Relations (New York: Routledge, 2013); Corneliu Bjola, 'Diplomacy as World Disclosure: A Fractal Theory of Crisis Management', The British Journal of Politics and International Relations, vol. 18, no. 2 (2016), pp. 335-350; and Costas M. Constantinou, 'Everyday Diplomacy: Mission, Spectacle and the Remaking of Diplomatic Culture', in Dittmer and McConnell (eds), Diplomatic Cultures and International Politics, pp. 23-40. 
aristocratic traditions of diplomacy. Instead, they are encouraged to recognize a much richer tradition and the existence of alternative diplomatic cultures and praxis, both within and beyond the conventional, state-centric approach; ${ }^{77}$ cultures that enhance the diplomatic ethic of responsibility, that challenge and balance the diplomatic ethic of ultimate ends.

To be attentive to the montage of the diplomatic spectacle — the gathering and framing of images projecting specific visual narratives - is to open up to spatio-temporalities that underscore how diplomacy operates on the human mental screen and indeed in everyday life through assemblage and more-thanhuman agency, often with unexplored consequences. ${ }^{78}$ This article and the essay film that accompanies it are invitations to explore further the increasing role of (still and moving) images in everyday life and to study more intensely and deeply the complex implications - political as well as ethical — of using imagery in diplomacy.

Costas M. Constantinou is Professor of International Relations at the University of Cyprus. He has published numerous books and articles on diplomacy, conflict and international political theory, most recently the co-authored Transprofessional Diplomacy (Leiden: Brill, 2017) and the co-edited The SAGE Handbook of Diplomacy (London: Sage, 2016). His first documentary The Third Motherland (2011) - is accessible at https://www:youtube.com/ watch? $v=J V K H 7 t h X 8 v c$.

77 Costas M. Constantinou, 'Between Statecraft and Humanism: Diplomacy and its Forms of Knowledge', International Studies Review, vol. 15, no. 2 (2013), pp. 141-162; Noé Cornago, Plural Diplomacies: Normative Predicaments and Functional Imperatives (Leiden: Martinus Nijhoff, 2013); and Dittmer and McConnell (eds), Diplomatic Cultures and International Politics.

78 Jason Dittmer, 'Theorizing a More-than-Human Diplomacy: Assembling the British Foreign Office, 1839-1874', The Hague Journal of Diplomacy, vol. 11, no. 1 (2016), pp. 78-104. 